\title{
THE VITA SANCTI BRENDANI \\ IN THE RUSSIAN NATIONAL LIBRARY: \\ A LATIN MANUSCRIPT OF THE TWELFTH CENTURY
}

\author{
FYODOR KORANDEY
}

\section{Introduction}

The Russian National Library Vita Sancti Brendani is the part of the manuscript Lat.0.v.I No. 199 (ff. 53-96), which contains that text as well as biblical and patristic sententiae (Excerpta ex Biblia, ss. patrum et philosophorum operibus cum summario, ff.1-52) and the vita of Saint Symphorian of Autun (Passio S. Symphoriani Augustodunensis, ff. 96-102). The general catalogue of Russian National Library (RNL) Latin manuscripts dates this manuscript to the $12^{\text {th }}$ century (Bernardskaya et al. 1983: 50-1). ${ }^{1}$ The codex consists of 102 parchment leaves of $155 \times 105 \mathrm{~mm}$, which originally formed two separate manuscripts written by two twelfth-century hands. The text is written in a single column. Every page contains twenty lines of early Gothic book script (transitional from late Carolingian minuscule) in black ink. It is scantily ornamented with rubrics and small red initials. There are no colophons or chapter divisions, except ff.56v (Igitur sanctus Brendanus... See: Selmer, 1959: 9), 57r (Transactis iam quadraginta dierum... See: Selmer, 1959: 10), 58r (Ascendit autem sanctus Brendanus... See: Selmer, 1959: 12), 63r (Profectique sunt ad nauim... See: Selmer, 1959: 20). In these cases we have red and black small initials.

Notwithstanding its title, the text of our manuscript is in fact a version of the Navigatio Sancti Brendani, a prose work which enjoyed greater popularity throughout the Middle Ages than the Irish vitae Brendani. This is not surprising because of the rather late origin of the tale normally so designated. It was noted by David Stifter that the expression navigatio (the verbal noun of navigare) occurs only once, in the title of the story, and therefore it can be supposed that Vita Sancti Brendani was in fact the original title of the story (Stifter 1997: 56). ${ }^{2}$ The manuscript tradition of the tale supports this suggestion. As the title, navigatio occurs for the first time only in

\footnotetext{
${ }^{1}$ D. Dumville dates the opening section of the manuscript (ff.1-52) to the first half of the $12^{\text {th }}$ century and the second section, which includes vitae sanctorum (ff.53 v.-102), to the middle of the $12^{\text {th }}$ century. See D. Dumville's notes in the copy of Selmer's edition of Navigatio Sancti Brendani, which is now held by the Manuscripts Department of the National Library of Russia.

${ }^{2}$ See "Dieses Fehlen des Begriffs navigatio im Text selbst könnte vielleicht ein Hinweis darauf sein, dass der Titel ursprünglich gar nicht Navigatio St. Brendani gelautet hat, sondern tatsächlich Vita St. Brendani, wie es in vielen Handschriften ja der Fall ist.”
} 
a $15^{\text {th }}$-century manuscript (Brussels, BR 1160). Carl Selmer states in his article that "the expression Vita Sancti Brendani has been used in the case of almost half of all manuscripts extant, the reason being that the scribes, ignorant of the actual Vita, regarded the expression Vita Sancti Brendani more indicative and far superior to Liber Brendani, or any other similar expression" (Selmer 1949: 181-2).

This paper addresses questions concerning the place of this version of the Vita Sancti Brendani kept at the Russian National Library in the manuscript tradition of the text. Giving the amount of manuscripts, a detailed comparison of manuscript Lat.0.v.I No. 199 with its closely related manuscripts would be a challenging undertaking that cannot be attempted here. Therefore, my observations with regard to the provenance, hypothetical ancestry and the audience of this manuscript are unavoidably preliminary. As far as I know, scholars have been aware of this version since 1990: in that year it was microfilmed for Breandán Ó Cíobháin; David Dumville has consulted it; and there is a reference to it as "the newly authenticated St. Petersburg manuscript" in Chapter 1 of Patricia Rumseys' (2007: 4) book. However, the extent of her awareness of this text is not clear. It is obvious that this noteworthy manuscript has not received much scholarly attention so far, and in this respect, this article is an attempt to rectify this deficiency.

\section{The RNL Navigatio in relation to other versions}

First of all, let us consider the total number of the Navigatio manuscripts and the place which our version may hold in relation to the others. The first list of manuscripts known to me appeared in an article by Carl Steinweg in 1893. In Steinwegs' list all known manuscripts were grouped according to the places where they were kept. This list included 74 manuscripts from Belgium, Germany, England, France, Italy, Austria and Switzerland. At least 8 (or possibly even 10) manuscripts of this number date back to the $11^{\text {th }}$ century, and 11 (or possibly 13) manuscripts date back to the $12^{\text {th }}$ century (Steinweg 1893: 1-48). The next attempt to assemble a full list of manuscripts and to correct and supplement the earlier brief lists of Thomas Hardy (1862: 159-61) and James Kenny (1929: 414) was made by Mario Esposito. His list included 99 manuscripts (Esposito 1938: 328-346). The list of the Latin manuscripts of the Navigatio (about 120 manuscripts) which was published by Carl Selmer in an appendix to his 1959 edition of the Navigatio was the most complete for a long time (Selmer 1959: 105-116). This expanded list is the only one which provides a sufficient basis for a comparative study. It includes the annotations, places of provenance, incipits and explicits etc. of the manuscripts. Finally, the more recent list from The Legend of Saint Brendan: A Critical bibliography of Glynn Burgess and Clara Strijbosch should be mentioned (Burgess \& Strijbosch 2000: 13-26). It seems that this list was compiled (in part) by the 
late Giovanni Orlandi, who prepared a new critical edition of the Navigatio. This list includes 126 items, which is more than the number listed in any other previous discussion, but sadly the descriptions of the manuscripts provided are not detailed enough.

It has been said above that accepted date of manuscript Lat.0.v.I No. 199 is the middle of $12^{\text {th }}$ century. Let us consider the context of the manuscripts of the Navigatio which already existed in the twelfth century. The total number of these manuscripts is 48 , namely 2 (or 3) manuscripts from the $10^{\text {th }}$ century, 14 (or 13 ) manuscripts from the $11^{\text {th }}$ century and 32 (25) manuscripts from the $12^{\text {th }}$ century (Selmer 1959: xxvii). It should be noted, however, that new additions to existing list of early manuscripts are very rare. For example, Selmer knew of only 3 manuscripts from the $10^{\text {th }}$ century, 14 manuscripts from the $11^{\text {th }}$ century and 23 manuscripts from the $12^{\text {th }}$ century. Selmer also knew of almost all manuscripts which were added later to the list of the Critical Bibliography by Burgess and Strijbosch, but he dates them to a later period. No $10^{\text {th }}$ century manuscripts were added to the list of the Critical Bibliography, but there are yet one $11^{\text {th }}$ century fragment (Vatican, Bibliotheca Apostolica) and three $12^{\text {th }}$ century ones (1 Milan and 2 Porto manuscripts). In 1949 Carl Selmer wrote of "the inaccessibility of so many versions hidden away in unexplored archives of remote countries" (1949: 177). In this respect, the Russian National Library can be described as one of these "unexplored archives'. The Russian manuscript is an example of one of the "hidden" manuscripts in question.

\section{Characteristics of RNL manuscript}

The next step in our inquiry is to define the boundaries of the group to which our manuscript can belong. Any preliminary suggestion on this issue is unavoidably hypothetical because of the number of manuscript witnesses (48 manuscripts). In order to put the manuscript in its context, it is necessary to say some words about the stemmata genealogy of the manuscripts of the Navigatio, which was elaborated by Carl Selmer in his edition. Selmer traces the spread of the tale from tenth-century Lotharingia. He also established four principal regions in the early evolution of the Navigatio. The first region was twelfth-century Southern Germany:

Trier, where the oldest preserved Navigatio was written toward the end of the tenth century, was the starting point of the particular manuscript branch which reached out toward Southern Germany and touched such cities as Ratisbon, Ranshofen and Salzburg, thus becoming the source for numerous Southern German and Austrian copies (Selmer 1949: 179). 
The second region was the French-speaking districts adjacent to Lotharingia in the $11^{\text {th }}$ century (Limoges, Rouen, Alançon). The third was twelfth-century Rhineland, and the last was Brabant, Holland and Northern Germany in the twelfth century. Selmer's stemma codicum can be represented in a simplified form as a map, connecting places of provenance in a single period:

$\alpha$-group (Lotaringia, prototype manuscript, now lost, $10^{\text {th }}$ century)

$\beta$-group (Holland, Brabant, Northern Germany, $11^{\text {th }}$ century, Ghent manuscript, base manuscript of Selmer's edition)

$\gamma$-group (South Germany, 10-12 ${ }^{\text {th }}$ c.; As a sample of this group, I consulted the manuscript Munich Clm 29890 (29061) of Bayerische Staatsbibliothek).

$\delta$-group (France, 11-12 ${ }^{\text {th }}$ c.; As a sample of this group, I consulted the manuscript of Alançon).

$\varepsilon$-group (Rhineland Germany, $10-11^{\text {th }}$ c.; Manuscripts of this group were not available for consultation).

A collation of a portion of the Russian Library text with representatives of the manuscripts-families identified by Selmer indicates that the Russian text belongs to the $\gamma$-group of Selmer's edition on the basis of the following considerations:

\subsection{Common readings.}

Selmer (1959: xlvi) concluded that the community of origin of the manuscripts of the $\gamma$-group is clearly shown by 67 cases of peculiar common readings. It appears that our manuscript shares characteristic features of this group and agrees with all the examples which were provided by Selmer.

\begin{tabular}{|l|c|l|}
\hline \multicolumn{2}{|c|}{ Shared omissions } \\
\hline \multicolumn{1}{|c|}{ Selmer's version } & omissions of $\gamma$-group & \multicolumn{1}{c|}{ Lat.0.v.I No.199 } \\
\hline $\begin{array}{l}\text { Ailbei, et ibi celebrabitis } \\
\text { Natiuitatem Domini (11, } \\
107)\end{array}$ & \multicolumn{1}{|c|}{ et } & $\begin{array}{l}\text { Ailbei, ibi celebrabitis } \\
\text { Natiuitatem Domini (f. 67v) }\end{array}$ \\
\hline $\begin{array}{l}\text { Illi uero usque ad uesperas } \\
\text { asportabant (16, 36) }\end{array}$ & uero & $\begin{array}{l}\text { Ita usque <ad uesperas> } \\
\text { adsportabant carnes (77v) }\end{array}$ \\
\hline $\begin{array}{l}\text { suam massam, semper } \\
\text { reuerentes in illorum } \\
\text { officinas }(23,28)\end{array}$ & semper & $\begin{array}{l}\text { suam massam, reuerentes in } \\
\text { illorum officinas (86r) }\end{array}$ \\
\hline $\begin{array}{l}\text { Nam furcas ferreas, in } \\
\text { quibus pannus pendet, } \\
\text { illas dedi sacerdotibus } \\
\text { templi ad cacabos } \\
\text { sustinendos }(25,45)\end{array}$ & pannus & $\begin{array}{l}\text { Nam furce ferree ubi pendet } \\
\text { illas dedi sacerdotibus } \\
\text { templi ad cacabos } \\
\text { sustinendos (89r) }\end{array}$ \\
\hline $\begin{array}{l}\text { precepit sancto Brendano } \\
\text { ut omnes fratres (26, 30) }\end{array}$ & & $\begin{array}{l}\text { precepit sancto Brendano } \\
\text { omnes fratres (91r) }\end{array}$ \\
\hline
\end{tabular}




\begin{tabular}{|c|c|c|}
\hline $\begin{array}{l}\text { id [est] unum piscem, } \\
\text { attulit ad tres dies }(26,27)\end{array}$ & attulit & $\begin{array}{l}\text { id est unum piscem ad tres } \\
\text { dies (93r) }\end{array}$ \\
\hline \multicolumn{3}{|c|}{ Shared amplifications } \\
\hline Selmer's version & additions of $\gamma$-group & Lat.O.v.I No. 199 \\
\hline $\begin{array}{l}\text { Ablatisque omnibus de } \\
\text { naui, coram sancto patre } \\
\text { locutus est, dicens }(11,80)\end{array}$ & ad illos idem uir & $\begin{array}{l}\text { Ablatisque omnibus de naui } \\
\text { coram sancto patre locutus } \\
\text { est idem uir dicens }(66 \mathrm{v})\end{array}$ \\
\hline $\begin{array}{l}\text { usque ad tertiam horam. } \\
\text { Tunc beatus Brendanus } \\
\text { immolauit agnum et } \\
\text { dicebat fratribus }(15,42)\end{array}$ & $\begin{array}{l}\text { cum suis fratribus } \\
\text { ascendens nauim }\end{array}$ & 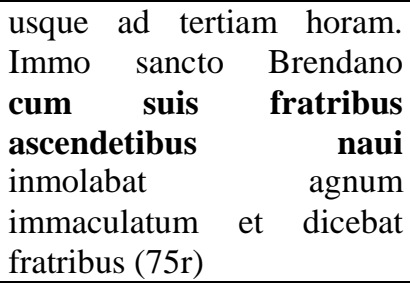 \\
\hline $\begin{array}{l}\text { cumque ibi cum suis } \\
\text { famulis celebrauit festa } \\
\text { Paschalia, predictus iam } \\
\text { procurator uenit ad illos }\end{array}$ & $\begin{array}{l}\text { usque ad octauas } \\
\text { pentecosten }\end{array}$ & $\begin{array}{l}\text { cumque ibi cum suis } \\
\text { famulis celebrauit festa } \\
\text { Paschalia usque ad octauas } \\
\text { pentecosten predictus iam } \\
\text { procurator uenit ad illos } \\
\text { (75v) }\end{array}$ \\
\hline
\end{tabular}

A more comprehensive collation of the Russian National Library manuscript with the other manuscripts of $\gamma$-group remains a matter for future study, but it seems that a comparison of the sample from our manuscript with two samples of manuscripts from the other groups and with the sample from the Selmer's critical edition may be sufficient to indicate that the Russian National Library text belongs to the $\gamma$-group.

Variant readings of the Navigatio Sancti Brendani in the samples of manuscripts

Munich Clm 29890 (29061) $\gamma$-group (A), Alençon BM $14 \delta$-group (B), RNL Lat.0.v.I No. 199 (C), Selmer's edition (S).

[55] Sicut illam uides modo, ita [56] ab inicio mundi permansit. Indigesne aliquid cibi aut potus siue [57] uestimenti ? Unum annum enim es in hac insula et non gustasti de [58] cibo aut de potu. Numquam fuisti oppressus somno, nec nox te [59] operuit. Dies namque est semper sine cecitate tenebrarum hic. [60] Dominus noster Jhesus Christus lux ipsius est.' Confestim inchoa- [61] -uimus iter et predictus uir ille nobiscum peruenit usque ad litus ubi [62] erat nauicula nostra. Ascendentibus autem in nauim, raptus est idem [63] uir ab oculis nostris; et uenimus per predictam caliginem ad insulam [64] deliciosam. At ubi fratres nos uiderunt, exultabant exultacione magna [65] de aduentu nostro et plorabant de absencia nostra multi tam tem- [66] -poris, dicentes: 'Cur, patres dimisistis uestras oues sine pastore in ista [67] silua errantes? Nouimus abbatem nostrum frequenter a nobis / dis- [68] cedere in aliquam partem, sed 
nescimus in quam, et ibidem com- [69] -morari aliquando uno mense, aliquando duabus ebdomadibus seu una [70] edbomada uel plus minusue.'

57 Unum annum enim ABS / unum enim annum $\mathrm{C}$

(Selmer's edition, cap. 1, 55-70)

57 in hac insula et non ACS / in hac insula fuisti et non add B

57 et non gustasti de cibo et potu ACS / et non indiguisti cibo et potu B

58 nec nox te operuit ABS / nec nox te cooperuit C

59 semper sine cecitate tenebrarum hic S / semper sine cecitate ulla tenebrarum hic $\mathrm{ABC}$

61 et predictus uir ille nobiscum S / et ille predictus uir nobiscum AC / et ille vir praedictus nobiscum $B$

62 ubi erat nauicula nostra S / ubi erat nostra nauicula AC / litus ubi erat navicula nostra om B

62-63 Ascendentibus... caliginem om B

65-66 plorabant de absentia nostra multi tam temporis, dicentes BS / plorabant de absentia nostra multo tempore dicentes AC

66-67 oues sine pastore in ista silua errantes ABS / oues in ista insula sine pastore errantes C

68-69 et ibidem commorari S / demorari AC / commemorari B

69 uno mense $\mathrm{S} /$ unum mensem $\mathrm{ABC}$

69 duabus ebdomadibus SB / duas ebdomadas AC

69-70 una ebdomada ABS / unam ebdomadam C

70 ebdomada uel plus minusue BS / ebdomada plus minusue AC

As one can see from the above examples, manuscripts $\mathrm{A}$ and $\mathrm{C}$ do not show significant differences between them; they are more closely related than other manuscripts and form an easily recognisable group. Thus, RNL Lat.0.v.I No.199 may be designated as a representative of the $\gamma$-group identified by Selmer.

\subsection{Lacunae}

Another aspect, characteristic for a sub-set of the manuscripts of the $\gamma$-group's (the so called $\mu$-subgroup, 7 manuscripts, $10^{\text {th }}-12^{\text {th }}$ centuries) is the so-called short ending, which concludes the story with the words recto itinere ad locum suum reuersus est, thus eliminating the $29^{\text {th }}$ and final chapter of the Navigatio Sancti Brendani (Selmer 1959: xlvi). This trait is shared by our text. The last words of manuscript Lat.0.v.I No.199 are: recto itinere reuersus est ad locum suum.

The absence of the last chapter is intriguing. Selmer suggested that it was part of the original story, but some other authors do not accept the validity of its inclusion in a critical edition. David Stifter (1997: 107), for instance, concluded that this chapter was added later to the original version. His conclusions were based on a number of considerations including: 
a) Except for the last chapter, the whole text of Navigatio Sancti Brendani has a circular structure. The description of the Terra repromissionis sanctorum which is given in Chapter 18 corresponds word for word with Barrind's account of the journey to the Insula deliciosa and thence to the Terra repromissionis sanctorum in Chapter 1. The structure of the tale is dunad-like, to use an Old Irish term, the final part of the tale echoes the first, it starts and ends with the same word: transacto uero spacio quasi unius hore, circumfulsit nos lux ingens, et apparuit terra spaciosa et herbosa pomiferosa ualde $(1,38$ 39) and Post spacium uero unius hore iterum circumfulsit eos lux ingens, et nauis stetis ad litus. Porro ascendentibus de naui, uiderunt terram spaciosam ac plenam arboribus pomiferis sicut in tempore autumnali $(28,9-13)$.

b) In Chapter 29 the rather clear and plain language of the tale undergoes critical changes. A number of words occur in the text, which previously had not appeared, e.g.: accidere, amabilis, aspectus, attestatio, certus, congratulari, cuncti, deprivari, disponere, eventus, gloriosus, gratulans, interiacere, intervallum, munire, notare, obitus, portentum, postremo, privatus, velocitas. Some of the words completely change their meaning (caritas, discipulus, sacramentum). In fact, a total of 27 out of 94 words (excluding amen, explicit), or $29 \%$ of this chapter, are new. It is clear for any reader that the syntax of chapter 29 is more intricate and tedious, than that of the previous chapters. The author of the additional section seems to be aiming for a more elevated style than the author of the preceding part. If Stifters' hypothesis about the $\mu$ subgroup-centered tradition of the short ending is correct, our manuscript belongs to this group.

\subsection{Griffin}

In addition, two of manuscripts of the $\gamma$-group and our manuscript share a notable palaeographic feature. The initial letter of Sanctus, the first word of the text, in manuscripts N (Clm. 22248) and H (Vat. Pal. Lat. 217, St. Stephan, Würzburg. $12^{\text {th }} \mathrm{c}$.) has the shape of a griffin with its head turned back and its tongue ending in six spirals (Selmer 1959: xxxix). The initial letter of the text in Lat.0.v.I No.199 has an almost identical form.

\section{Audience and type of the manuscript Lat.0.v.I No.199}

And, finally, what was the audience of our manuscript? Before trying to find the answer to this question, I would like to refer to a recent book by Jude Mackley (2008). It is a comparative study of the functions of the fantastic element in two versions of the legend of St. Brendan, the early Latin legend 
(ninth-century Navigatio) and the twelfth-century Anglo-Norman reworking of this narrative. The most essential aspect of this work is the description of some distinct audiences of the tale. As Mackley wrote:

the Navigatio was composed for three distinct ecclesiastical audiencesthe brethren of a monastery dedicated to Brendan; the pilgrims that the monastery hoped to attract, and for the edification of the wider monastic community - who may well have heard travellers' tales to islands in the Atlantic, but the narrative itself remains an allegory for spiritual life and an observation of monastic hours and feast days (Mackley 2008: 2-3).

The point concerning the distinct and specific audiences is an important one. Bearing in mind the date and the provenance of the Russian manuscript, we can now turn to look at the contents of the large codices in which the closest relatives of our version ( $\gamma$-group) are found. What can we find in such compilations?

\section{Navigatio Sancti Brendani in the manuscripts of $\gamma$-group (Content and context)}

a) München, Bayerische Staatsbibliothek, Clm 17740, ff. 1v-36v. $10^{\text {th }}$ century. M of Selmer's edition, St. Mang Abbey, Bavaria (Halm 1878: 119-120):

f. 1. Vita S. Brendani.

f. 37. Vita Adam et Aeuae.

f. 47. Symeonis uita

f. 59. Caesarii omeliae IX ad monachos.

f. 89 Aduentus exceptioque corporis B.Benedicti in agrum Floriacensem 'Cum diu gens Longobadorum'

f. 98. De uita S. Hieronymi.

f. 107. 'Qualiter et quando undeque B. mart. Senesii (Synesii) atque Theopontii corpora ad Nonatulae coenobium ducta fuerint'.

b) München, Bayerische Staatsbibliothek, Clm 17139, ff.169r-174v. 12 century. Q of Selmer's edition, Schäftlarn, Bavaria (Halm 1878: 82):

Vitae Patrum.

f. 169 Brandani abbatis uita. In tegumentis diplomata a. 1410. Scripsit Marchwardus sub Abbate Eberhardo (a. 1153-1160).

c) München, Bayerische Staatsbibliothek, Clm 22248, ff. 70v-90r. 12 century. N of Selmer's edition, Windberg, Bavaria (Halm 1881: 33):

f. 1. Vita Sylvestri papae.

f. 25. Malachiae uersus 'Spernere mundum'. 
f. 26. Bernhardi Clar. uita Malachiae,

f. 59 sermo de eodem.

f. 61 Vita Fursei.

f. 70 Vita Brendani.

f. 90 Passio Cholomanni.

f. 94 Epistola (Hieronymi 20)

f. 97 Passio Gereonis et sociorum.

f. 99 Vita Theudarii

f. 103 Vita Cassiani

f. 112 Vita Heinrici imp.

f. 123 Historia fundationis Windeberg usque ad a. 1158.

f. 127. Vita Alexii. Haec sub abbate Gebehardo, scripsit Petrus monachus.

d) Paris, Bibliothèque Nationale de la France, Codex lat. 3784. ff. 103r-108v. F of Selmer's edition, Limoges, France (Thomas 1988: 56-66):

f. 2-13, 14-42 Homiliariorum fragmenta (apocryphes de S. Augustin)

f. 43-102 Compilationes Ademari Cabannensis e Vitis Patrum et (f. 54-86) operibus s. Hieronymi

f. 103-108 Vitae s. Brendani

ff. 108 et aliorum.

As can be seen above these collections can be classified as homiliaries and legendaries (passionaries). In theory, it is possible to draw a distinction between these two broad categories of compilations, but in practice they were mixed collections. These collections were designed for monastic reading, giving saints' legends for their specific days and patristic sermons for certain occasions, etc.

As a representative of the $\gamma$-group, RNL Navigatio should be considered a product of the monastic culture of Bavarian Klosterland between the $10^{\text {th }}$ and $12^{\text {th }}$ centuries. The scribe of the oldest manuscript of this family (Munich, BS, Clm 29890 (29061), Tegernsee, Bavaria, 11-12 ${ }^{\text {th }}$ century; U of Selmer's edition) was Froumund of Tegernsee (c. 960-c. 1008), a poet and grammarian. According to Peter Christian Jacobsen, the original Gorze-Trier tradition of the Navigatio Sancti Brendani, which had its beginning in Lotharingia around the year 800 , possibly could have found its way to Bavaria through the agency of Froumund. Living in Köln around 900, this cleric could have copied some early texts originated from St. Maximin's Abbey of Trier (Jacobsen 2000: 90).

\section{Conclusion}

To sum up, there are three points that should be emphasised here. First of all, the Russian National Library is the owner of a unique $12^{\text {th }}$-century version of the Navigatio, which was completely unknown for many years. It is one of 
only five manuscripts of this period which were added to the list of Navigatio manuscripts since Selmer's edition. Secondly, RNL Lat.0.v.I No.199 may be assigned to the $\gamma$-group in Selmer's stemma codicum. Therefore it should be considered as a product of the monastic culture of $10^{\text {th }}$ - to $12^{\text {th }}$-century Bavaria. Lastly, codex Lat.0.v.I No.199, which is part homiliary and part legendary, is an example of a type of manuscript which is characteristic for this culture.

Jonathan Wooding observes that the early Navigatio Sancti Brendani is a relatively homogeneous text, though it has a copious textual tradition, and that the readings of the manuscripts bear witness to an original common version. "Most variants are relatively minor and in many cases the readings of the original text can be established with confidence" (O'Meara \& Wooding 2002: 14). There is an edition of the Navigatio which is based on a single manuscript; it reproduces the exact text of a particular version (Vincent 1982). Such an edition is useful when studying the history of the entire textual tradition. It may be the most convenient way to make the Russian version available for scholars in the field. I hope that, in collaboration with fellow scholars, this work will soon be carried out. ${ }^{3}$

Tyumen State University, Russia

\section{References}

Bernardskaya, E.V., Voronova, T.P., Vyalova, S.O., eds., 1983, Латинские рукописи V-XII веков Государственной Публичной библиотеки им. M.E. Салтыкова-Щедрина. Краткое описание для Сводного каталога рукописей, хранящихся в СССР. [Latin Manuscripts of $5-12^{\text {th }} \mathrm{c}$. from State M.E. Saltykov-Schedrin Public Library. Short Description for the Comprehensive Catalogue of the Manuscripts in USSR] Part 1, Leningrad.

Brincken, A.-D., 2000, 'Das Weltbild der irischen Seefahrer-Heiligen Brendan in der Sicht des 12. Jahrhunderts', Cartographica Helvetica 21-22, 17-21.

Burgess, G., Strijbosch, C., 2000, The Legend of St. Brendan. A Critical Bibliography. Dublin: RIA.

Esposito, M., 1938, 'Sur la Navigatio Sancti Brendani et sur ses versions italiennes', Romania 64, 328-46.

\footnotetext{
${ }^{3}$ Without doubt, surprising discoveries about the early history of Navigatio Sancti Brendani will be made. As an example of such discovery, let me point to another previously unlisted manuscript of Navigatio Sancti Brendani (Brincken 2000: 17-21). This is a $12^{\text {th }}$-century version from the private collection of the late Albert Knoepfli (Kartographiesammlung aus der Dr. Albert Knoepfli-Stiftung), which has been held in the local museum of Thurgay, Switzerland (Ortsmuseum von Bischofszell im Kanton Thurgau) since 1975. It has an Isidorian mappa mundi on the reverse side of the parchment. It has the same appearance as many Bavarian manuscripts.
} 
Halm, K., 1878, Catalogus codicum manu scriptorum Bibliothecae Regiae Monacensis. T. 4: Catalogus codicum latinorum. Pars 3: Clm 15121-21313, Monachii.

Halm, K., 1881, Catalogus codicum manu scriptorum Bibliothecae Regiae Monacensis. T. 4: Catalogus codicum latinorum. Pars 4: Clm 21406-27268, Monachii.

Hardy, T.D., 1862, Descriptive Catalogue of Materials relating to the History of Great Britain and Ireland, to the End of the Reign of Henry VII, Vol. I (I), London: Longmans.

Jacobsen, P.Ch., 2000, 'Die Navigatio Sancti Brendani', in: Ertzdorff, X., ed., Beschreibung der Welt. Zur Poetik der Reise- und Länderberichte. Vorträge eines interdisziplinären Symposiums vom 8. bis 13. Juni 1998 an der JustusLiebig-Universität Gießen (Chloe: Beihefte zum Daphnis, Bd. 31), Amsterdam, 63-95.

Kenney, J.F., 1929, The Sources for the Early History of Ireland. vol. I: Ecclesiastical, New York: Columbia University Press.

Mackley, J.S., 2008, The Legend of St Brendan: A Comparative Study of the Latin and Anglo-Norman Versions (The Northern World, 39), Leiden: Brill.

O' Meara, J.J., Wooding, J., 2002, 'The Latin Version of the Voyage of St. Brendan', in: Barron, W.R.J., Burgess, G. S, eds., The Voyage of Saint Brendan: Representative Versions of the Legend in English Translation, Exeter: University of Exeter Press.

Rumsey, P., 2007, Sacred Time in Early Christian Ireland: The Monks of the Nauigatio and the Céli Dé in Dialogue to Explore the Theologies of Time and the Liturgy of the Hours in pre-Viking Ireland, London : T. and T. Clark.

Selmer, C., 1949, 'A Study of the Latin Manuscripts of the Navigatio Sancti Brendani', Scriptorium. International Review of Manuscript Studie, 3, 177-82. Selmer, C., ed., 1959, Navigatio Sancti Brendani from Early Latin Manuscripts, Notre Dame (Indiana).

Steinweg, C., 1893, 'Die handschriftlichen gestaltungen der lateinischen Navigatio Brendani', Romanische Forschungen 7, Erlangen: Verlag von Fr. Junge, 1-48.

Stifter, D., 1997, Philologica Latino-Hibernica: Navigatio Sancti Brendani. Diplomarbeit zur Erlangung des Magistergrades der Philosophie eingereicht an der Geisteswissenschaftlichen Fakultät der Universität Wien, Wien.

Thomas, M., ed., 1988, Catalogue général des manuscrits latins de la Bibliothèque Nationale de la France. T. VII (№ 3776 à 3835). Homéliaires, Paris: BNF.

Vincent, G., 1982, Recherches sur la Navigation de St Brendan. Manuscrit latin d' Alençon, Aix: Université de Provence. 
